$(\mathrm{H}, \mathrm{H})=0.9 \mathrm{~Hz}, 1 \mathrm{H}, 10 \mathrm{~b}-\mathrm{H}), 5.07(\mathrm{ddd}, J(\mathrm{H}, \mathrm{H})=10.0 \mathrm{~Hz}, J(\mathrm{H}, \mathrm{H})=2.0 \mathrm{~Hz}$, $J(\mathrm{H}, \mathrm{H})=0.9 \mathrm{~Hz}, 1 \mathrm{H}, 10 \mathrm{a}-\mathrm{H}), 5.75(\mathrm{ddd}, J(\mathrm{H}, \mathrm{H})=17.0 \mathrm{~Hz}, J(\mathrm{H}, \mathrm{H})=$ $10.0 \mathrm{~Hz}, J(\mathrm{H}, \mathrm{H})=8.0 \mathrm{~Hz}, 1 \mathrm{H}, 9-\mathrm{H}), 7.02\left(\mathrm{AA}^{\prime} \mathrm{BB}\right.$, analyzed as AB, $\left.\Delta v_{A B}=54.0 \mathrm{~Hz}, J(\mathrm{H}, \mathrm{H})=9.0 \mathrm{~Hz}, 4 \mathrm{H}, \mathrm{Ph}-\mathrm{H}\right), 7.54(\mathrm{~m} .1 \mathrm{H}, 2-\mathrm{H}) \cdot{ }^{13} \mathrm{C}$ NMR $\left(50.3 \mathrm{MHz}, \mathrm{C}_{2} \mathrm{D}_{2} \mathrm{Cl}_{4}, 100^{\circ} \mathrm{C}\right): \delta=19.80^{*}(\mathrm{C}-6) .27 .71^{*}(\mathrm{C}-5), 30.65(\mathrm{C}-7)$, 35.96 (C-4 a), $40.26(\mathrm{C}-4), 41.24(\mathrm{C}-8), 50.45\left(\mathrm{OCH}_{3}\right), 51.57\left(\mathrm{OCH}_{3}\right), 55.45$ $\left(\mathrm{Ph}-\mathrm{OCH}_{3}\right), 58.87\left(\mathrm{C}-1^{\prime}\right), 59.73$ (C-8 a), $\left.93.47(\mathrm{C}-3), 114.6\left(2 \times \mathrm{C}^{\prime}\right)^{\prime}\right), 115.8$ (C-10), $128.8\left(2 \times C-3^{\prime}\right), 129.1\left(\mathrm{C}-2^{\prime}\right), 140.4(\mathrm{C}-9), 146.1(\mathrm{C}-2), 159.6\left(\mathrm{C}-5^{\prime}\right), 167.9$ (CO), 175.6. The asterisk indicates peaks that are not yet unambiguously assigned.

Received: April 4, 1991 [Z 4551 IE] Publication delayed at the authors' request German version: Angew'. Chem. 103 (1991) 1665

CAS Registry numbers:

3a. 93589-90-3; 3b, 116952-07-9; 3c, 116952-08-0; 3d, 136953-20-3; 13, $136953-19-0 ; 14,136953-18-9 ; 17 \mathrm{~b}, 136953-17-8 ; 17 \mathrm{c}, 136953-12-3 ; 17 \mathrm{~d}$, $136953-11-2 ; 18$ a, 136953-15-6; 18b, 136953-13-4; 18c, 136953-14-5; 18d, 136953-16-7.

[1] L. F. Tietze, M. Bratz, Chem. Ber. 22 (1989) 997; Liebigs Ann. Chem (1989) 559; S. D. Larsen, P. A. Grieco, J. Am. Chem. Soc. 107 (1985) 1768 S. F. McCann, L. E. Overman, ibid. 109 (1987) 6107; G. W. Daub, D. A. Heerding. L. E. Overman, Tetrahedron 44 (1988) 3919; D. J. Hart. T. K Yang, J. Org. Chem. 50 (1985) 235; H. Hiemstra. M. H. A. M. Sno, R. J. Vijn. W. N. Speckamp, ibid. 50 (1985) 4014; H. Rapoport, Lect. Heterocycl. Chem. 4 (1978) 47; L. F. Tietze, G. Kinast, Angew. Chem. 88 (1976) 261: Angew. Chem. Int. Ed. Engl. 15 (1976) 239.

[2] L. F. Tietze, A. Bergmann, G. Brill, K. Brüggemann, U. Hartfiel, E. Voß, Chem. Ber. 122 (1989) 83.

[3] L. F. Tietze. A. Bergmann, K. Brüggemann, Synthesis 1986, 190; L, F. Tietze. K. Brüggemann, Angew. Chem. 94 (1982) 550; Angew. Chem. Int. Ed. Engl. 21 (1982) 539; L. F. Tietze, A. Bergmann, ibid. 97 (1985) 135 and 24 (1985) 127.

[4] A. Sausins, G. Duburs, Heterocycles 27 (1988) 269; ibid. 27 (1988) 291; D. M. Stout. A. I. Meyers, Chem. Rev. 82 (1982) 223; F. Bossert, H. Meyer, E. Wehinger, Angew. Chem. 93 (1981) 755; Angew. Chem. Int. Ed. Engl. 20 (1981) 762 .

[5] J. D. Winkler. P. M. Hershberger, J. Am. Chem. Soc. 11/ (1989) 4852.

[6] L. F. Tietze. M. Ruther, Chem. Ber. 123 (1990) 1387; L. F. Tietze, J. R. Wünsch, Synthesis 1990, 985, 1204.

[7] M. W. Rathke, M. Nowak, J. Org. Chem. 50 (1985) 2624.

[8] L. F. Tietze, K. Brüggemann, unpublished results.

[9] R. P. Polniaszek, S. E. Belmont, R. Alvarez, J. Org. Chem. 55 (1990) 215; D. Schinzer (Ed.): Selectivities in Lewis Acid Promoted Reactions, Kluwer, Dordrecht 1989

[10] P. Deslongchamps: Stereoelectronic Effects in Organic Chemistry, Pergamon, Oxford 1986.

\section{Three- and Fourfold Bridgehead-Substituted Tribenzotriquinacenes **}

\section{By Andreas Schuster and Dietmar Kuck*}

\section{Dedicated to Professor Michael Hanack \\ on the occasion of his 60th birthday}

The threefold benzo-stabilized triquinacene 1 , one of the three prototypic centrotriindanes, provides, in contrast to the parent compound, an opportunity to study reactions at the four bridgehead positions through the formation of stable, well-crystallizing compounds. As we were recently able to show in collaboration with de Meijere et al., ${ }^{[2]}$ the threefold benzoannelation in the case of 1 also contributes considerably to the stabilization of anionic and olefinic derivatives of this system. We now present the particularly stable olefin 3 , which is readily accessible from 1 and which affords a

[*] Dr. D. Kuck, Dr. A. Schuster

Fakultät für Chemie der Universität

Universitätsstrasse 25, W-4800 Bielefeld 1 (FRG)

[**] Benzoannelated Centropolyquinanes, Part 10. This work was supported by the Deutsche Forschungsgemeinschaft.-Part 9: D. Kuck, A. Schuster, R. A. Krause, J. Org. Chem. 56 (1991) 3472-3495. variety of novel bridgehead-substituted tribenzotriquinacenes in some, in part, unusual reactions.

The tribenzoquinacene 1 is accessible via two routes ${ }^{[2,3]}$ and, despite its extremely poor solubility, can be converted almost quantitatively into the $C_{3 v}$ symmetrically substituted tribromo derivative 2 (Scheme 1). Aminolysis of 2 with di-

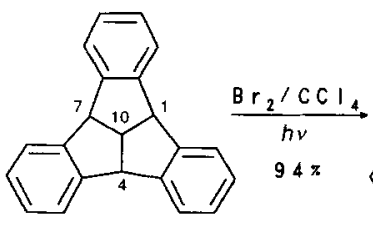

1

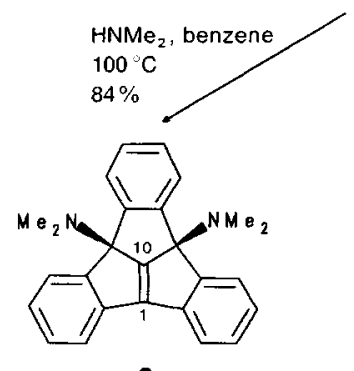

3

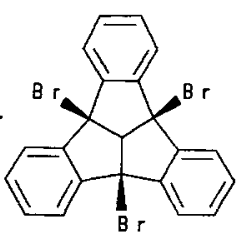

2
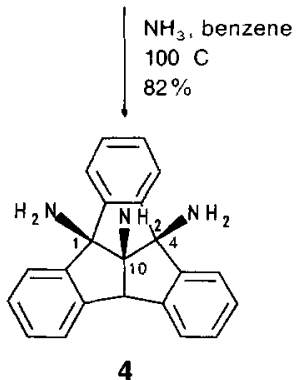

4
Scheme 1. Syntheses starting from tribenzotriquinacene 1

methylamine affords the tribenzodihydroacepentalene 3, also in high yields. In contrast to the analogously prepared dihydroacepentalenes, ${ }^{[6]}$ crystalline 3 is absolutely air-stable-a remarkable property in view of the two strongly pyramidalized olefinic atoms $\mathrm{C} 1$ and $\mathrm{C} 10 .{ }^{[7,8]}$ The analogous bis(trimethylsilyl) compound is likewise accessible from 1 , but is far less stable than $3^{[2,9]}$

Surprisingly, ammonolysis of 2 leads to the triamino compound 4 with $C_{\mathrm{s}}$ symmetric substitution. The constitution of this compound, which is also obtainable in good yields, is unequivocally confirmed by its NMR spectrum (Table 1). The 1,4,10-triamine is thus the first triquinacene with heterosubstitution at the central bridgehead to be obtained in a direct synthesis. ${ }^{[10,11]}$ Attempts to explain the unexpected reaction of 2 with ammonia by further experiments were hitherto not very successful. ${ }^{[12]}$ The intermediary analogue of 3 ( $\mathrm{H}$ instead of $\left.\mathrm{Me}, \mathbf{3}^{\prime}\right)$ is, in contrast to 3 , apparently not sufficiently kinetically stabilized. ${ }^{[13]}$

Two of the reactions of 3 carried out with 1,3-dipolar agents deserve special mention, namely those with azides (Scheme 2). 3 reacts smoothly with phenyl azide to give the regioisomer 9, a triquinacene substituted by nitrogen at all four bridgehead atoms. Presumably, steric factors are mainly responsible here for the high regioselectivity. On the other hand, with trimethylsilyl azide we could not isolate the expected cycloaddition products, despite all measures to exclude moisture. Instead the 1-azido-4,7-bis(dimethylamino) derivative 6 was obtained in good yields, once again as a well-crystallizing compound. The NMR data and thermolysis results indicate that the three outer bridgehead atoms carry substituents (Table 1) $;^{[14]}$ conclusive chemical proof (Scheme 2) was provided by the reduction of 6 with $\mathrm{LiAlH}_{4}$ to give 7, and the subsequent methylation according to Eschweiler and Clarke to give 1,4,7-tris(dimethylamino)tribenzotriquinacene $\mathbf{8}$, whose $C_{3 \mathrm{y}}$ symmetric constitution unambiguously followed from the ${ }^{1} \mathrm{H}$ and ${ }^{13} \mathrm{C}$ NMR spectra (Table 1). 
A number of fourfold heterosubstituted tribenzotriquinacenes can be prepared from the olefin 3 . Thus 3 reacts at low temperatures with bromine to give the dibromide 10 (Scheme 2), which can be converted as expected with dimethylamine into the, once again, $C_{3 y}$ symmetric 10-bromo-1,4,7-tris(dimethylamino)tribenzotriquinacene 11. All attempts at the solvolysis of the $\mathrm{C} 10-\mathrm{Br}$ bond have so far failed. ${ }^{[15]}$

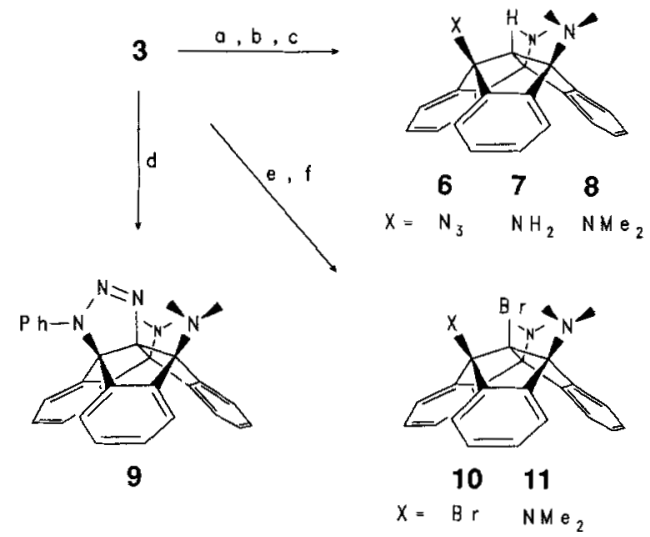

Schema 2. a) $\mathrm{Me}_{3} \mathrm{SiN}_{3} / \mathrm{CH}_{2} \mathrm{Cl}_{2}$, room temperature, $1 \mathrm{~d}\left(76 \%\right.$ 6); b) $\mathrm{LiAlH}_{4} /$ THF, RT, $6 \mathrm{~h}(96 \% 7)$; c) $\mathrm{HCO}_{2} \mathrm{H} / \mathrm{CH}_{2} \mathrm{O} / \mathrm{H}_{2} \mathrm{O}, 130^{\circ} \mathrm{C}, 2 \mathrm{~h}(80 \% 8) ;$ d) $\mathrm{PhN}_{3}$ $\mathrm{CH}_{2} \mathrm{Cl}_{2}, \mathrm{RT}, 1 \mathrm{~d}\left(94 \%\right.$ 9); e) $\mathrm{Br}_{2} / \mathrm{CH}_{2} \mathrm{Cl}_{2},-60{ }^{\circ} \mathrm{C}$, addition over $6 \mathrm{~h}(85 \%$ 10); f) $\mathrm{HNMe}_{2} / \mathrm{C}_{6} \mathrm{H}_{6}, 100^{\circ} \mathrm{C}, 1 \mathrm{~d}(54 \%$ 11).

Furthermore, we found an unexpected direct entry to 1,10 cyclopropa-annelated tribenzoquinacenes starting from 3 . Cyclopropatriquinacenes of type $\mathbf{1 5}$ are to our knowledge unknown so far; but several saturated derivatives have, however, been synthesized very recently from the dodecahedrane series. ${ }^{[16,17]}$ It therefore seemed interesting to check whether tribenzotriquinacene analogues are stable compounds despite the conjugation of the central cyclopropane ring with two $\pi$ systems. ${ }^{[18]}$

The olefin 3 adds diazomethane and 2-diazopropane quantitatively with formation of the tetracyclic dihydropyrazoles 12 and 13, respectively (Scheme 3). The similarly high yields and the almost identical NMR chemical shifts of the three $N$-substituted bridgehead atoms point to the same constitution of the two tetracyclic frameworks. Since considerable steric hindrance is assumed for the diazopropane adduct
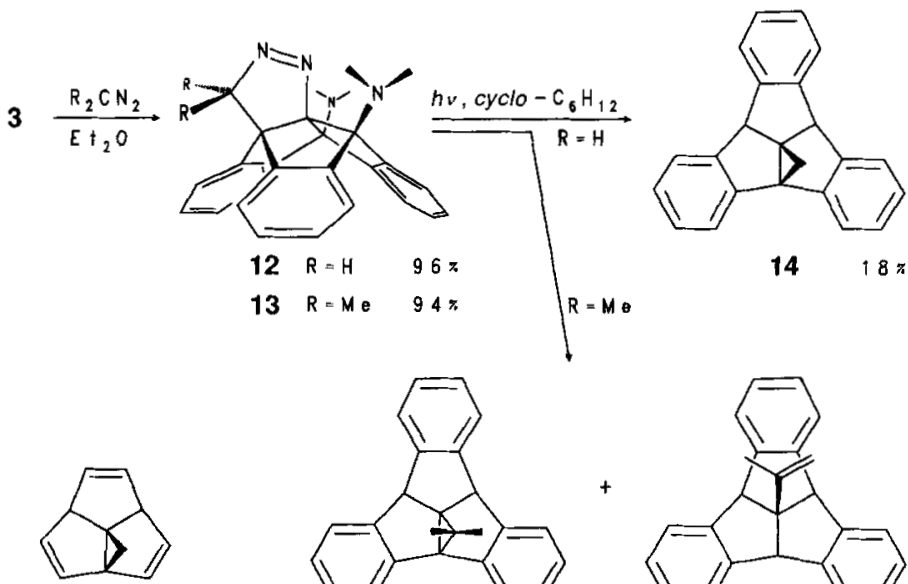

14
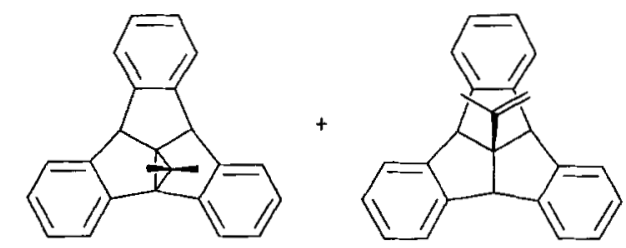

15

$1619 \%$ with a $\mathrm{C}\left(\mathrm{CH}_{3}\right)_{2}$ substituent on $\mathrm{C} 10,12$ and 13 are assigned the structures shown, with a centro- $\mathrm{N}=\mathrm{N}$ group.

Irradiation of a suspension of $\mathbf{1 2}$ in cyclohexane at room temperature (quartz filter) leads with complete deamination to the tetracycle 14. Actually the product is formed in only $18 \%$ yield, together with large amounts of polymeric material, but it can be isolated in pure form by medium pressure chromatography (MPLC) and slow crystallization. Surprisingly, it is very soluble compared to many other triben-

Table 1. Physical data of selected compounds [IR(KBr), 'H NMR $\left(\mathrm{CDCl}_{3}\right.$, $\left.300 \mathrm{MHz}),{ }^{13} \mathrm{C} \mathrm{NMR}\left(\mathrm{CDCl}_{3}, 75 \mathrm{MHz}\right), \mathrm{MS}(\mathrm{EI}, 70 \mathrm{eV})\right]$.

2: $\mathrm{IR}: \tilde{v}\left[\mathrm{~cm}^{-1}\right]=3083,3066,3014,1469,1460,1273,1207,{ }^{1} \mathrm{H}$ NMR $3 \mathrm{AA}^{\prime} \mathrm{BB}^{\prime}$ spin systems $\delta_{\mathrm{A}}=7.68(6 \mathrm{H}), \delta_{\mathrm{B}}=7.37(6 \mathrm{H}), \delta=5.58(\mathrm{~s}, 1 \mathrm{H}) ;{ }^{13} \mathrm{C}$ NMR: $\delta=143.6$ (s), 130.6 (d), 125.1 (d), 89.2 (d), 67.1 (s); MS: $m / z 435,437$, $439\left([M-\mathrm{Br}]^{\oplus} ; 51,95,51\right), 277(78), 276(68), 274(21), 138(100), 137$ (33)

3: IR: $\tilde{v}\left[\mathrm{~cm}^{-1}\right]=3059,2977,2964,2852,2827,2818,1466,1459,1272,1056$; ${ }^{t} \mathrm{H}$ NMR: $\delta=7.87\left(\mathrm{~d}, 2 \mathrm{H},{ }^{3} J=6.1 \mathrm{~Hz}\right), 7.57\left(\mathrm{~d}, 2 \mathrm{H},{ }^{3} J=6.4 \mathrm{~Hz}\right)$, AA'BB spin system $\delta_{\mathrm{a}}=7.43(2 \mathrm{H}), \delta_{\mathrm{B}}=7.20(2 \mathrm{H}), \delta=7.32-7.28(\mathrm{~m}, 4 \mathrm{H}), 2.56(\mathrm{~s}$, $12 \mathrm{H}) ;{ }^{\mathrm{f}}{ }^{3} \mathrm{C} \mathrm{NMR}: \delta=164.1$ (s), $154.4(\mathrm{~s}), 153.8(\mathrm{~s}), 144.1$ (s), 139.3(s), 127.8(d) 126.7 (d), 126.6 (d), 124.8 (d), 122.2 (d), $78.2(\mathrm{~s}), 41.5\left(\mathrm{CH}_{3}\right) ; \mathrm{MS}: \mathrm{m} / z 364\left(M^{\oplus}\right.$, 1), $321(14), 319(8), 277$ (26), $276(100), 159$ (2), $138(9)$

4: IR: $\check{v}\left[\mathrm{~cm}^{-1}\right]=3645,3316(\mathrm{br}), 3064,3025,2872,1476,1453,1219 ;{ }^{1} \mathrm{H}$

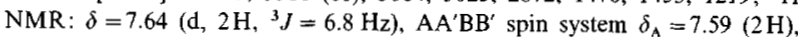
$\delta_{\mathrm{B}} \approx 7.25\left(2 \mathrm{H}\right.$, masked), $\delta=7.40\left(\mathrm{~d}, 2 \mathrm{H},{ }^{3} \mathrm{~J}=6.7 \mathrm{~Hz}\right) .7 .29-7.21(\mathrm{~m}, 4 \mathrm{H}), 4.48$ (s, $1 \mathrm{H}), 1.87$ (br.s, $6 \mathrm{H}, \mathrm{NH}_{2}$ ); ${ }^{13} \mathrm{C}$ NMR: $\delta=148.1$ (s), 146.7 (s), 142.0 (s), 129.0 (d), 128.7 (d), 128.1 (d), 124.1 (d), 123.9 (d), 83.3 (s), 75.2(s), 64.0 (d); MS: $m / z 325\left(M^{\oplus}, 57\right), 308(69), 307$ (33), 291 (100), $280(22), 265(18), 231$ (10)

6: Colorless crystals, m.p. $203-208^{\circ} \mathrm{C}$ (from $\mathrm{CH}_{2} \mathrm{Cl}_{2} / \mathrm{MeOH}$ ); IR: $\tilde{y}\left[\mathrm{~cm}^{-1}\right]=$ $3073,3034,2984,2950,2861,2821,2091\left(\mathrm{~N}_{3}\right), 1476,1454,1242,1235,1225 ;{ }^{1} \mathrm{H}$ NMR: masked AA'BB' and ABCD spin systems $\delta=7.63-7.59(\mathrm{~m}, 2 \mathrm{H}), 7.58$ $7.55(\mathrm{~m}, 2 \mathrm{H}), 7.53-7.50(\mathrm{~m}, 2 \mathrm{H}), 7.32-7.28(\mathrm{~m}, 6 \mathrm{H}), 4.32(\mathrm{~s}, 1 \mathrm{H}, 10-\mathrm{H}), 2.26$ (s, 12 H, $\left.\mathrm{CH}_{3}\right) ;{ }^{13} \mathrm{C} \mathrm{NMR:} \delta=146.3(\mathrm{~s}), 144.8(\mathrm{~s}), 142.6(\mathrm{~s}), 129.7$ (d), 129.1 (d), 124.7 (d), 124.5 (d), 123.3 (d), 83.7 (s), 80.6 (s), 55.3 (d), $41.0\left(\mathrm{CH}_{3}\right) ; \mathrm{MS}: \mathrm{m} / \mathrm{z}$ $407\left(M^{\oplus}, 2\right), 364(20), 362(24), 319(62), 291(100), 290(88), 276(13)$

8: IR: $\tilde{v}\left[\mathrm{~cm}^{-1}\right]=3069,3030,2988,2930,2817,2781,1474,1452,1228,1060$, 1011,$769 ;{ }^{1} \mathrm{H}$ NMR: $3 \mathrm{AA}^{\prime} \mathrm{BB}^{\prime}$ spin systems $\delta_{\mathrm{A}}=7.53(6 \mathrm{H}), \delta_{\mathrm{B}}=7.22(6 \mathrm{H})$, $\delta=4.37(\mathrm{~s}, 1 \mathrm{H}, 10-\mathrm{H}), 2.35\left(\mathrm{~s}, 18 \mathrm{H}, \mathrm{CH}_{3}\right) ;{ }^{13} \mathrm{C} \mathrm{NMR}: \delta=145.9(\mathrm{~s}) .128 .6(\mathrm{~d})$, 124.2 (d), 83.9 (s), $41.7\left(\mathrm{CH}_{3}\right)$; the signal for $\mathrm{C10}$ presumably lies at $\delta=77.8$; MS (EI, $70 \mathrm{eV}): m / z 409\left(M^{\oplus}, 2\right), 365$ (37), $364(48), 321(100), 320(34), 277$ (36), $276(59), 160.5(11), 138(15)$

9: IR: $\tilde{v}\left[\mathrm{~cm}^{-1}\right]=3089,3067,3029,3005,2986,2940,2875,2840,1596,1488$, 1473, 1462, 1270, 1224, $1003 ;{ }^{1} \mathrm{H}$ NMR: $\delta=7.57$ (d, $\left.2 \mathrm{H},{ }^{3} J=7.9 \mathrm{~Hz}\right), \mathrm{AA}^{\prime} \mathrm{BB}^{\prime}$ spin system $\delta_{\mathrm{A}}=7.54(2 \mathrm{H}), \delta_{\mathrm{B}} \approx 7.30(2 \mathrm{H}), \delta=7.43\left(\mathrm{~d}, 2 \mathrm{H},{ }^{3} J=7.6 \mathrm{~Hz}\right)$. $7.39-7.23(\mathrm{~m}, 5 \mathrm{H}), 7.14(\mathrm{~s}, 4 \mathrm{H}), 2.83\left(\mathrm{~s}, 6 \mathrm{H}, \mathrm{CH}_{3}\right), 2.37\left(\mathrm{~s}, 6 \mathrm{H}, \mathrm{CH}_{3}\right) ;{ }^{3} \mathrm{C}$ NMR: $\delta=146.8$ (s), 144.4 (s), 140.6 (s), 140.4 (s), 129.4 (d), 129.3 (d), 129.1 (d), 128.7 (d), 127.3 (d), 126.5 (d), 125.4 (d), 124.6 (d), 124.3 (d). 117.0 (s), 86.9 (s), $83.1(\mathrm{~s}), 41.1\left(\mathrm{CH}_{3}\right), 39.7\left(\mathrm{CH}_{3}\right)$; MS: $m / z 483\left(M^{\oplus}, 5\right), 411(16), 378(100), 367$ (84), $335(40), 320(20), 290$ (24), 276 (49), 183.5 (7); UV/VIS ( $n$-heptane, $\left.c=1.25 \times 10^{-4} \mathrm{M}\right): \lambda_{\max }[\mathrm{nm}](\varepsilon)=295(6280), 276(8130), 268(9180)$

11: IR: $\tilde{v}\left[\mathrm{~cm}^{-1}\right]=3075,3031,2980,2927,2884,2800,1473,1453,1259,1205$, 1065, 757; ${ }^{1} \mathrm{H}$ NMR: $3 \mathrm{AA}^{\prime} \mathrm{BB}^{\prime}$ spin system $\delta_{\mathrm{A}}=7.42(6 \mathrm{H}), \delta_{\mathrm{B}}=7.19(6 \mathrm{H})$, $\delta=2.73\left(18 \mathrm{H}, \mathrm{N} \cdot \mathrm{CH}_{3}\right) ;{ }^{13} \mathrm{C} \mathrm{NMR} ; \delta=\mathrm{ca} .144$ (s), 128.5 (d), 125.1 (d), 113.0 (s), $86.0(\mathrm{~s}), 40.0\left(\mathrm{CH}_{3}\right) ; \mathrm{MS}: m / z 487,489\left(M^{\oplus} ; 16,16\right), 443,445(21,20), 363$ (10), $320(23), 278(17), 277(21), 276(53), 58(100)$

14:IR: $\tilde{v}\left[\mathrm{~cm}^{-1}\right]=3065,3036,3010,2888,1473,1455,1254,1100,755,733 ;{ }^{1} \mathrm{H}$ NMR: $\delta=7.63-7.60(\mathrm{~m}, 2 \mathrm{H}), 7.53-7.50(\mathrm{~m}, 2 \mathrm{H}), 7.43-7.40(\mathrm{~m}, 2 \mathrm{H}), 7.21-$ $7.14(\mathrm{~m}, 6 \mathrm{H}), 4.67(\mathrm{~s}, 2 \mathrm{H}), 1.69\left(\mathrm{~s}, 2 \mathrm{H}, \mathrm{CH}_{2}\right) ;{ }^{13} \mathrm{C} \mathrm{NMR}: \delta=149.7(\mathrm{~s}), 145.0$ (s), 144.4 (s), 127.1 (d), 126.7 (d), 125.2 (d), 124.9 (d), 124.6 (d), 124.2 (d), 53.9 (d), $46.9(\mathrm{~s}), 41.5(\mathrm{~s}), 29.5\left(\mathrm{t}, \mathrm{CH}_{2}\right) ; \mathrm{MS}: \mathrm{m} / \mathrm{z} 292\left(\mathrm{M}^{\oplus}, 100\right), 291(49), 289(28)$, 280 (15), $276(14), 215$ (8), $146 \quad(4), 138$ (12); UV/VIS ( $n$-heptane, $\left.c=4.45 \times 10^{-5} \mathrm{M}\right): \lambda_{\max }[\mathrm{nm}](\varepsilon)=277(2670), 270.5(2760)$, ca. $264(1800)$ 16: IR: $\tilde{v}\left[\mathrm{~cm}^{-1}\right]=3065,3035,3015,2978,2927,2873,1475,1464,1455,752$, 737, 721 ; ${ }^{1} \mathrm{H}$ NMR: AA'BB' spin system $\delta_{\mathrm{A}}=7.53(2 \mathrm{H}), \delta_{\mathrm{B}} \approx 7.15(2 \mathrm{H}$, masked), $\delta=7.43-7.40(\mathrm{~m}, 4 \mathrm{H}), 7.18-7.12(\mathrm{~m}, 4 \mathrm{H}), 4.52(\mathrm{~s}, 2 \mathrm{H}), 1.06(\mathrm{~s}, 6 \mathrm{H})$; ${ }^{13} \mathrm{C} \mathrm{NMR}: \delta=151.6(\mathrm{~s}), 144.9$ (s), 143.3 (s), 127.1 (d), 127.0 (d), 126.6 (d), 125.4 (d), 124.5 (d), 123.7 (d), 56.2 (s), 52.6 (d), 51.7 (s), 34.8 (s), $18.7\left(\mathrm{CH}_{3}\right) ; \mathrm{MS}: \mathrm{m} / \mathrm{z}$ $320\left(M^{\ominus}, 100\right), 305(55), 289(22), 279(27), 278(21), 277(20), 276(26), 178(7)$, 144.5 (11). $138(13)$; UV/VIS ( $n$-heptane, $\left.c=5.0 \times 10^{-5} \mathrm{M}\right): \lambda_{\max }[\mathrm{nm}](\varepsilon)=277$ $(3000), 270.5(2740)$, ca. $264(1920)$

17: IR: $\tilde{v}\left[\mathrm{~cm}^{-1}\right]=3065,3027,2986,2974,2927,1633,1485,1476,1456,1375$, 875, 753, 733; ${ }^{\mathrm{I}} \mathrm{H}$ NMR: $3 \mathrm{AA}^{\prime} \mathrm{BB}^{\prime}$ spin systems $\delta_{\mathrm{A}}=7.45(6 \mathrm{H}), \delta_{\mathrm{B}}=7.18(6 \mathrm{H})$, $\delta=5.05(\mathrm{~s}, 1 \mathrm{H}), 4.92(\mathrm{~s}, 3 \mathrm{H}), 4.87(\mathrm{~s}, 1 \mathrm{H}), 1.90\left(\mathrm{~s}, 3 \mathrm{H}, \mathrm{CH}_{3}\right) ;{ }^{13} \mathrm{C} \mathrm{NMR}$ : $\delta=148.3$ (s), 145.0 (s), 127.5 (d), 124.1 (d), 108.1 (t), 70.2 (s), 60.6 (d), 20.1 $\left(\mathrm{CH}_{3}\right) ; \mathrm{MS}: m / z 320\left(M^{\oplus}, 100\right), 305(44), 290(10), 289(15), 279(16), 278$ (27), $277(18), 276(23), 178(11), 145$ (11) 138 (14)

Scheme 3. Synthesis of cyclopropatriquinacenes. 
zotriquinacenes. ${ }^{[2-5]}$ The ${ }^{1} \mathrm{H}$ NMR, ${ }^{13} \mathrm{CNMR}$, and mass spectra unequivocally confirm the structure of 14 (Table 1 ).

Under the same conditions the diazopropane adduct 13 furnishes the tetracycle 16 in $19 \%$ yield; the main product, however, is the ring-opened 10-(propen-2-yl)tribenzotriquinacene 17. Also these two compounds are spectroscopically unambiguously identifiable (Table 1) and like 14 are very stable in crystalline form. 17 is the first triquinacene with an unsaturated substituent on the central $\mathrm{C}$ atom and ought to be convertible into further, interesting $\mathrm{C} 10$-substituted tribenzotriquinacenes. ${ }^{[4,5,19]}$

The photolytic deamination of the cycloadducts 12 and 13 is surprising. ${ }^{[20]}$ In the tribenzotriquinacenes this process is possibly facilitated by radicals generated in the course of the deazotization and is additionally favored by the formation of highly conjugated isoindene intermediates. Also consistent with this hypothesis is the ring-opening of 13 to give 17.

The diaminoolefin 3 and the bridgehead-substituted tribenzotriquinacenes presented here for the first time prompt further investigations. Thus, the strictly ecliptic orientation of up to four vicinal substituents on the convex side of the molecule with the rigid triquinacene framework could lead to concerted dipolar interactions. The consequences of the particular stereochemistry of such highly functionalized spherical molecules for structure and reactivity should be studied in more detail.

\section{Experimental Procedure for Selected Compounds}

2: A suspension of tribenzotriquinacene $1(560 \mathrm{mg}, 2.00 \mathrm{mmol})$ in tetrachloromethane $(100 \mathrm{~mL})$ was treated dropwise at $50^{\circ} \mathrm{C}$ with $6.00 \mathrm{~mL}$ of a $1.0 \mathrm{M}$ solution of bromine in tetrachloromethane $(6.00 \mathrm{mmol})$. The suspension was additionally irradiated with a photolamp $(500 \mathrm{~W})$. After very rapid uptake of the bromine (effervescence!), the solvent was removed and the yellow-brown residue recrystallized from toluene. $2(970 \mathrm{mg} ; 94 \%)$ was obtained in the form of brownish platelets; m.p. $320-325^{\circ} \mathrm{C}$ (decomp.).

3: $2(517 \mathrm{mg}, 1.00 \mathrm{mmol})$ was frozen in anhydrous benzene $(10 \mathrm{~mL})$ in a test tube $(180 \mathrm{~mm} \times 22 \mathrm{~mm})$ containing a small stirring rod. Dimethylamine $(20 \mathrm{~mL})$ was condensed into the tube which was then placed in a steel autoclave (190 $\mathrm{mm} \times 26 \mathrm{~mm}$, Roth); the autoclave was sealed tight and the reaction mixture stirred magnetically in an oil bath at $100^{\circ} \mathrm{C}$ for $20 \mathrm{~h}$. After the reaction mixture cooled, the excess amine was removed and the contents of the test tube were diluted with $20 \mathrm{~mL}$ of dichloromethane and $20 \mathrm{~mL}$ of water. After extractive workup with $\mathrm{CH}_{2} \mathrm{Cl}_{2}$, drying with $\mathrm{Na}_{2} \mathrm{SO}_{4}$, and removal of the solvent, a light-brown crystalline residue was obtained, which upon recrystallization from $\mathrm{CH}_{2} \mathrm{Cl}_{2} / \mathrm{MeOH}$ afforded $305 \mathrm{mg}(84 \%)$ of 3 in the form of colorless needles; m.p. $231^{\circ} \mathrm{C}$.

4: As described for $3,2(517 \mathrm{mg}, 1.00 \mathrm{mmol})$ was allowed to react in benzene (precooled to $-40^{\circ} \mathrm{C}$ ) with liquid ammonia $(10 \mathrm{~mL})$ in a sealed tube. After workup and recrystallization from $\mathrm{CH}_{2} \mathrm{Cl}_{2} / n$-heptane $4(266 \mathrm{mg}, 82 \%)$ was obtained in the form of very fine, colorless needles; m.p. $248^{\circ} \mathrm{C}$ (decomp.). 9: A solution of $3(364 \mathrm{mg}, 1.00 \mathrm{mmol})$ in dichloromethane $(10 \mathrm{~mL})$ was treated with phenyl azide ( $300 \mathrm{mg}, 2.50 \mathrm{mmol}$ ) and the mixture stirred for $24 \mathrm{~h}$ at room temperature. Methanol was then added and the solution slowly evaporated down in a rotary evaporator until crystallization started. $5(514 \mathrm{mg}, 94 \%)$ was obtained in the form of colorless crystals; m.p. $251^{\circ} \mathrm{C}$.

10: To a solution of $3(364 \mathrm{mg}, 1.00 \mathrm{mmol})$ in anhydrous dichloromethane precooled to -60 C was added dropwise a $50.0 \mathrm{~mm}$ solution of bromine (1.00 mmol) in dichloromethane $(20 \mathrm{~mL})$ over $6 \mathrm{~h}$ using a fine-bore dropping funnel. After warming to room temperature, the suspension was evaporated down in vacue to a volume of $10 \mathrm{~mL}$ and treated with an equal amount of anhydrous ethyl acetate. The precipitated crystals were recovered by suction and recrystallized from $\mathrm{CH}_{2} \mathrm{Cl}_{2} / \mathrm{EtOAc.} 10(445 \mathrm{mg} ; 85 \%)$ was obtained in the form of yellow crystals; m.p. $216^{\circ} \mathrm{C}$ (decomp.).

11: Aminolysis of $10(131 \mathrm{mg}, 250 \mathrm{mmol})$, analogously to the reaction of 2 with dimethylamine, afforded a crude product, which, after recrystallization from $\mathrm{CH}_{2} \mathrm{Cl}_{2} / \mathrm{MeOH}$, furnished $11(65 \mathrm{mg} ; 54 \%)$ in the form of colorless crystals; m.p. 278 C (decomp.).

14, 16, and 17: The cycloadducts 12 (m.p. $272^{\circ} \mathrm{C}$ ) and 13 (m.p. $330^{\circ} \mathrm{C}$ ) were obtained from 3 by standard methods.-Photolysis: In a falling film photoreactor (Normag. $400 \mathrm{~mL}$ volume, quartz glass cooling and immersion tubes, Hanau T 718Z1, $500 \mathrm{~W}$ mercury vapor lamp) a suspension of $500 \mu \mathrm{mol}$ of 12 (204 mg) or $13(217 \mathrm{mg}$ ) in $350 \mathrm{~mL}$ of cyclohexane (Uvasol, Merck) was purged of dissolved oxygen by passage of nitrogen for $10 \mathrm{~min}$. After tempering to $20 \mathrm{C}$, the photoreaction was started; after about $10 \mathrm{~min}$ the reaction mixture clarified, and after a further $\mathbf{4 0} \mathrm{min}$ a renewed yellowish clouding was observed. Optimal yields were achieved after radiation for $90 \mathrm{~min}$. The reaction mixture was evaporated to dryness in a rotary evaporator.-Isolation of 14: The yellow tesidue was taken up in a little dichloromethane and filtered through silical gel. Finally, the nonpolar components (hydrocarbons) were isolated by MPLC (LiChroprep Si60, 40-60 $\mu \mathrm{m}$, Merck, $n$-hexane/dichloromethane 4/1) as a yellow oil. Subsequent yapor-diffusion crystallization furnished up to $26 \mathrm{mg}$ of 14 $(18 \%)$ in the form of very fine needles; m.p. $272{ }^{\circ} \mathrm{C}$.-Isolation of 16 and 17 : The yellow residue was taken up in a little dichloromethane and filtered with dichloromethane/n-hexane (1/1) through silica gel. The mixture of isomers (MS; $120 \mathrm{mg}, 75 \%$ ) was separated by MPLC with $n$-hexane/dichloromethane (5/1): $30 \mathrm{mg} \mathrm{(19 \% )}$ of 16 was obtained in the form of colorless crystals (m.p. $242^{\circ} \mathrm{C}$ ) and $76 \mathrm{mg}\left(48 \%\right.$ ) of 17 as colorless needles (m.p. $161^{\circ} \mathrm{C}$ ). - All the new compounds gave satisfactory elemental analyses.

Received: June 21, 1991; Revised: September 12, 1991 [Z 4739.4740 IE] German version: Angew. Chem. 103 (1991) 1717

CAS Registry numbers:

$1,120022-86-8 ; 2,137041-65-7 ; 3,137041-66-8 ; 4,137041-67-9 ; 6,137041-68-0$ $7,137041-69-1 ; 8,137041-70-4 ; 9,137041-71-5 ; 10,137041-72-6 ; 11,137041-$ $73-7 ; 12.137041-74-8 ; 13,137041-75-9 ; 14,137041-76-0 ; 16,137041-77-1 ; 17$, 137041-78-2; phenyl azide, 622-37-7; trimethylsilyl azide, 4648-54-8; diazomethane, 334-88-3; 2-diazopropane, 2684-60-8.

[1] D. Kuck in I. Hargittai (Ed.): Quasicrystals, Networks, and Molecules of Fivefold Symmetry, VCH Publishers, New York 1990, Chap. 19.

[2] D. Kuck, A. Schuster, B. Ohlhorst, V. Sinnwell, A. de Meijere, Angew Chem. 101 (1989) 626-628; Angew. Chem. Int. Ed. Engl. 28 (1989) 595 597

[3] D. Kuck, T. Lindenthal, A. Schuster, unpublished.

[4] The 10-methyl- and 10-ethyl-substituted tribenzotriquinacenes [3,5] are also readily substitutable threefold at the peripheral bridgehead atoms: A. Schuster, Dissertation, Universität Bielefeld 1991.

[5] D. Kuck, Angew. Chem. 96 (1984) 515-516; Angew. Chem. Int. Ed. Engl. 23 (1984) $508-509$.

[6] a) H. Butenschön, A. de Meijere, Tetrahedron Lett. 25 (1984) 1693-1696; b) Helv. Chim. Acta 68 (1985) 1658-1669; c) H. Butenschön, Dissertation, Universität Hamburg 1983.

[7] Review of pyramidalized olefins: a) W. T. Borden, Chem. Rev. 89 (1989) 1095-1109; b) P. M. Warner, ibid. 89 (1989) $1067-1093$; c) W. Luef, R. Keese, Top. Stereochem. 20 (1991) 231 -318; d) R. P. Johnson in J. F. Liebman, A. Greenberg (Eds.): Molecular Structure and Energetics, Vol. 3, VCH Publishers, Deerfield Beach 1986, Chap. 3; e) G. Szeimies in R. Abramovitch (Ed.): Reactive Intermediates, Vol. 3, Plenum, New York 1983, Chap. 5; f) A. Greenberg, J. F. Liebman: Strained Organic Molecules, Academic Press, New York 1978, Chap. 3.

[8] According to force field calculations (MM2 (87)) the pyramidalization angles [7a] in 3 are $\Phi(C 1)=39.3^{\circ}$ and $\Phi(C 10)=40.6^{\circ}$.

[9] B. Ohlhorst, Dissertation, Universität Hamburg 1989.

[10] Perchlorotriquinacenes have already been described: a) I. T. Jacobsen, $A c$ ta Chem. Scand. 21 (1967) 2235-2246; b) ibid. 26 (1972) 2477-2493; c) Chem. Scr. 5 (1974) 174-192.

[11] a) P. Bischof, Angew. Chem. 88 (1976) 609-610; Angew. Chem. Int. Ed. Engl. 15 (1976) 556; b) L. A. Paquette, S. V. Ley, S. Maiorana. D. F. Schneider, M. J. Broadhurst, R. A. Boogs, J. Am. Chem. Soc. 97 (1975) $4658-4667$; c) R. C. Bingham, P. von R. Schleyer, ibid. 93 (1971) 31893199; d) L. A. Paquette, Top. Curr. Chem. 79 (1979) 41-165.

[12] Attempts to add $\mathrm{NH}_{3}$ to 3 in $\mathrm{NH}_{4} \mathrm{Cl} / \mathrm{NH}_{3}$ were unsuccessful [4]

[13] We presume that $3^{\prime}$ forms a chelate complex 5 with $\mathrm{NH}_{4}^{\oplus}$, in which the ammonium proton orientated to the 1,10 double bond at tacks electrophilically at C1.

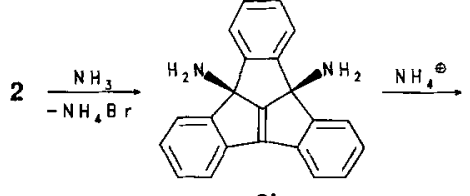

$3^{\prime}$

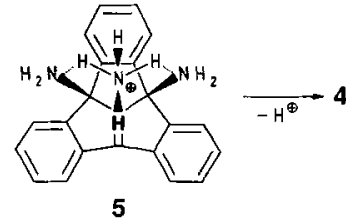

5
[14] D. Kuck, A. Schuster, unpublished

[15] No reaction was observed upon heating 11 with $\mathrm{NH}_{3}$ /benzene in an autoclave at $100^{\circ} \mathrm{C}$ and with $\mathrm{KOH} /$ triethyleneglycol up to $120^{\circ} \mathrm{C}$.

[16] a) L. A. Paquette, T. Kobayashi, J. C. Gallucci, J. Am. Chem. Soc. 110 (1988) 1305-1307; b) L. A. Paquette, T. Kobayashi, M. A. Kesselmayr, J. C. Gallucci, J. Org. Chem. 54 (1989) 2921-2930.

[17] a) R. Pinkos, J.-P. Melder, H. Fritz, H. Prinzbach, Angew. Chem. 102 (1990) 102-105; Angew. Chem. Int. Ed. Engl. 29 (1990) 92; b) I.-P. Melder, R. Pinkos, H. Fritz, H. Prinzbach, ibid. 102 (1990) 105-109 and 29 (1990) 95. 
[18] The increase in reactivity of centropolyquinanes by benzoannelation has already been reported: a) see Ref. [2], b) B. Paisdor, D. Kuck, J. Org. Chem. 56 (1991) $4753-4759$.

[19] C10-substituted triquinacenes: a) A. K. Gupta, G. S. Lannoye, G. Kubiak, J. Schkeryantz, S. Wehrli, J. M. Cook, J. Am. Chem. Soc. 111 (1989) 2169-2179; b) A. K. Gupta, J. M. Cook, U. Weiss, Tetrahedron Lett. 29 (1988) 2535-2538; c) X. Fu. J. M. Cook, ibid. 31 (1990) 3409-3412; d) B. Bengtson, Dissertation, Universität Hamburg 1986.

[20] Similar reductive $\mathrm{C}-\mathrm{N}$ cleavages have been observed in the photolytic decomposition of simple alkylamines: a) M. Mousson-Canet. J. C. Mani: Photochemistry and Molecular Reactions, Israel Program for Scientific Translations, Jerusalem 1972, p. 76; b) H. Dürr, W. Bujnoch, H. Kober, Methoden Org. Chem. (Houben Weyl) 4th ed 1952-, Vol.4/5b, p. 1076.

\section{1,3-Dipolar Cycloaddition as the Key Reaction in the Synthesis of Potent Renin Inhibitors}

By Günter Benz, * Rolf Henning, and Johannes-Peter Stasch

\section{Dedicated to Professor Karl Heinz Büchel on the occasion of his 60th birthday}

The renin-angiotensin system plays a central role in the pathogenesis of hypertension, mostly via the circulating vasoconstrictor angiotensin II. Although Angiotensin-Converting Enzyme Inhibitors (ACE Inhibitors) like captopril and enalapril ${ }^{[1]}$ have already been introduced to therapy, emphasis has been directed toward renin inhibitors in recent years because of their supposedly better selectivity. ${ }^{[2]}$ This increased interest has spurred synthetic work.

The most important reaction of renin is the proteolysis of the $N$-terminus of the globular protein angiotensinogen to the decapeptide angiotensin I. If the Leu-Val peptide bond in 1 cleaved in this reaction is replaced by an $(S)$-hydroxyethylene amide bond surrogate, renin inhibitors of the type 2 are obtained. ${ }^{[3]}$ Because these molecules resemble the transition state for cleavage by aspartyl proteases they possess a high affinity for renin ${ }^{[4]}$ but are not cleavable by the enzyme. Many renin inhibitors are rapidly degradated in vivo. This proteolysis should be hampered when the $C$-terminal amide bond is inverted. For this reason we propose renin inhibitors

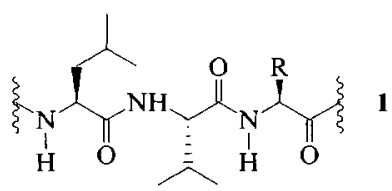
Leu $\mathrm{Val}$

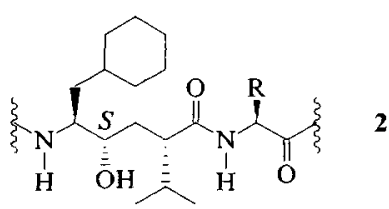<smiles>[R]C(NCC)C(=O)N[C@@H](C)C[C@H](O)[C@@H](CC1CCCCC1)N(C)C</smiles>

[*] Dr. G. Benz

Miles Research Center, Department of Chemistry 400 Morgan Lane, West Haven, CT 06516-4175 (USA)

Dr. R. Henning. Dr. J.-P. Stasch

Bayer AG, PH-FE

Postfach 1017 09, W-5600 Wuppertal 1 (FRG) of the type 3 which has both modifications - the inverted peptide bond and the hydroxyethylene unit. To maintain the topology of the peptide chain the adjacent amino acid must have the D-configuration.

The 1,3-dipolar cycloaddition of allylamines with $N$-benzylnitrones ${ }^{[5]}$ provides an easy access to this type of structure in which two stereocenters are generated early in the reaction sequence. The stereochemical course of the reaction can be influenced either by chiral nitrones ${ }^{[6]}$ or by chiral allylamines. ${ }^{[7]}$ The synthesis of the isoxazolidines and a potent renin inhibitor 14 is shown in Scheme $1 .^{[8]}$.

$N$-Boc-allylamine $4^{[9]}$ was prepared in four steps from $N$-Boc-phenylalanine. The subsequent reaction with benzylnitrone 5 at $140^{\circ} \mathrm{C}$ in mesitylene led after $8 \mathrm{~h}$ to a mixture of four diastereomeric isoxazolidines 7 , in the ratio 7 a $(1 R, 3 S$, $4 S) 0.75,7 \mathrm{~b}(1 S, 3 S, 4 S) 1.00,7 \mathrm{c}(1 S, 3 R, 4 S) 0.60,7 \mathbf{d}(1 R$,

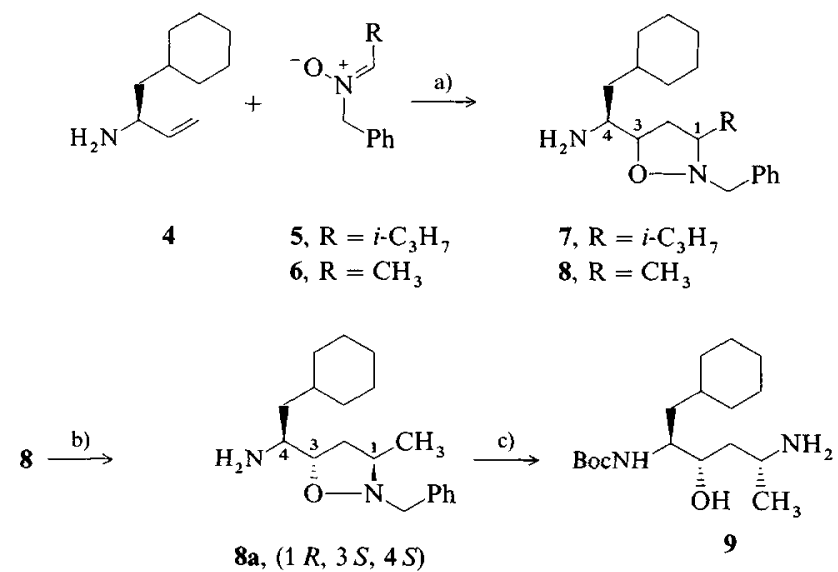<smiles>CCCCC(=O)N[C@@H](C)C[C@H](O)[C@H](N)CC1CCCCC1</smiles><smiles>CCCCC(=O)N[C@@H](C)C[C@@H](O)[C@H](CC1CCCCC1)NC(=O)[C@@H](N)C1CCCC1</smiles>

11

12<smiles>[Y7]C1CCN(C(=O)N[C@@H](Cc2ccccc2)C(=O)O)CC1</smiles>

13<smiles>CCCCC(=O)N[C@@H](C)C[C@H](O)[C@H](CC1CCCCC1)NC(=O)[C@H](NC(=O)[C@H](Cc1ccccc1)NC(=O)N1CCOCC1)C1CCCC1</smiles>

14

Scheme 1. a) Mesitylene, $140^{\circ} \mathrm{C}, 8 \mathrm{~h}, 52 \% 7$; b) $\mathrm{SiO}_{2}$, chromatography, $n$-hexane/ether $7: 3$; c) $\mathrm{NH}_{4}^{+} \mathrm{HCO}_{2}^{-}, 10 \% \mathrm{Pd} / \mathrm{C}, \mathrm{CH}_{3} \mathrm{OH}$, reflux, $60 \mathrm{~min}$; d) (n$\left.\mathrm{C}_{4} \mathrm{H}_{9} \mathrm{CO}\right)_{2} \mathrm{O}, \mathrm{NEt}_{3}, \mathrm{CH}_{3} \mathrm{OH}$; e) $4 \mathrm{~N} \mathrm{HCl}$, dioxane, $30 \mathrm{~min}$; f) (S)-cyclopentylglycine 11, dicyclohexylcarbodiimide (DCC), hydroxybenzotriazole (HOBT), disopropylethylamine (DIPEA); g) $4 \mathrm{~N} \mathrm{HCl}$, dioxane, $30 \mathrm{~min}$; h) morpholinocarbonyl-Phe 13, DCC, HOBT, DIPEA. 